\title{
Management of children who have swallowed button batteries
}

Small foreign bodies that are swallowed generally pass down the gut without any problem. Passage usually takes two to six days but may not uncommonly take two to four weeks. ${ }^{1}$ Most foreign bodies that cause trouble do so in the oesophagus. ${ }^{1}$ Button batteries are no exception. Reports of alarming and inappropriate surgical intervention have prompted this annotation.

The term 'battery' implies a number of power cells connected together in series, as in a car battery. and is used incorrectly in the title of this article. The button battery is a single cell and is used to power hearing aids, photographic equipment, digital watches, and hand held calculators. Although these cells are sealed, they contain corrosive and toxic chemicals. Lodgement in the oesophagus can lead to mucosal damage, and exposure to gastric acid is associated with a remote risk of leakage of the cell contents; hence the concern about children who have swallowed a button cell. The management should be as follows.

\section{Identify the type of cell swallowed}

There are four main types of button cell; mercury, silver, alkaline manganese, and lithium. Lithium cells are mostly used in watches where replacement is normally by a specialist, thereby limiting access to children. Lithium cells exhibit a potential of $3 \mathrm{~V}$ against the $1.5 \mathrm{~V}$ of the other systems but are more resistant to corrosion than other button cells. Lithium cells have not hitherto caused problems when swallowed, and their thin shape may facilitate gut transit. ${ }^{2}$ Silver cells seem to be non-toxic when swallowed. ${ }^{3}$ Thus it is worth trying to identify the type of cell, and this may be possible if the cell was new and the blister package is still available. Even without the package, if one can obtain an identical cell from the household this will be marked with a code number that will enable a poisons centre to identify the type of battery. Used batteries are potentially far less toxic than new ones. Discharged cells are less liable to leak or cause tissue injury, and in discharged mercury cells the mercuric oxide will be largely converted to elemental mercury, which is not absorbed. Finally, the mechanisms that corrode the cell container also discharge the cell, so it is the contents of a discharged cell that are the most relevant.

\section{Obtain a radiograph of the chest and abdomen}

Five per cent of those who have ingested button cells will have swallowed more than one cell, and it may not be known that the child has swallowed more than one cell. Thus an initial chest radiograph is needed in addition to an abdominal radiograph to ensure that a cell is not lodged in the oesophagus. The only children who have died from swallowing button cells had the cell lodged in the oesophagus, though in both cases the parents were unaware of cell ingestion, and presentation was delayed. ${ }^{56}$ In three other children a disc cell lodged in the oesophagus caused a tracheo-oesophageal fistula. 278

When undischarged cells are swallowed the electric current produced by the battery causes a rise in the $\mathrm{pH}$ at the anode surface." It is this (possibly combined with the local short circuit current through the tissues) and not leakage from the cell that can cause tissue burns." oesophagus is an indication for immediate removal. This is the one situation where endoscopy is likely to be successful, compared with the high failure rate when cells are in the stomach, duodenum, or colon. ${ }^{2}$ Endoscopic removal may be helped by the use of a Foley catheter ${ }^{11}$ or a magnet. ${ }^{12}$

\section{The cell is in the stomach}

Virtually all button cells that have reached the stomach will be passed spontaneously without any symptoms or complications. ${ }^{2}$

(1) Do not attempt to induce vomiting by giving an emetic. It does not work ${ }^{23}$ and carries the theoretical risk of fatal airway obstruction if by chance regurgitation of the cell is achieved.

(2) There is a logical basis for giving oral antacids that may reduce corrosion of the cell ${ }^{+}$and metoclopramide to enhance gastric emptying. Laxatives could help by speeding up intestinal transit. As most cells will pass safely through the gut quite unaided no firm directions can be given about the use of any of these drugs.

(3) There is disagreement about the need for admission to hospital if the cell has reached the stomach. Some recommend that the patient be sent home and the parents be advised to observe for fever, abdominal pain, vomiting, tarry or bloody stools, or decreased appetite and to confirm passage 
of the cell in the stools. ${ }^{2}$ We think that the need for admission depends on how far from the hospital the child lives and the social circumstances.

(4) Unless the cell is too large to negotiate the pylorus, endoscopic or surgical removal is not required. While a cell is in the stomach we recommend a daily abdominal radiograph to show passage from the stomach or to detect cell disassembly. If a cell does fall apart in the stomach the need for surgical removal is unclear. The hazard seems to be confined to mercury cells. The risk of toxicity depends on the size and the state of discharge of the cell and is a subject best discussed with a poisons centre. There has been one case where gastric disassembly of a mercury cell led to a potentially toxic concentration of mercury in the blood. ${ }^{13}$ The child was treated with chelating agents and suffered no symptoms of mercury toxicity. In this patient the cell fragments were surgically removed and intestinal lavage performed through an enterostomy and a gastrostomy, although whether either removal or lavage was of benefit in reducing the hazard of toxicity is far from clear. Even where a cell has fallen apart, spontaneous passage without toxicity is well documented. ${ }^{14}{ }^{15}$ Modestly raised urinary mercury concentrations have been recorded in one other patient in the presence of cell disassembly, ${ }^{16}$ though unpublished data suggest that this is uncommon, and the overall hazard of mercury toxicity from split button cells is thought to be minimal. ${ }^{2} 15$

\section{Cells that have passed the pylorus}

Virtually all will pass through the gut without problem. There is a very small risk of the cell becoming adherent to the gut mucosa, ${ }^{2}$ although many cases have been seen where a cell was clearly lodged at a single site for up to two weeks without adverse effect and with eventual spontaneous passage (T L Litovitz. Personal communication). Thus it is worth advising the parents to examine the stools to confirm that the cell has been passed and repeating a radiograph at roughly four day intervals. There is a single report of a cell becoming impacted in a Meckel's diverticulum. ${ }^{17}$

\section{Conclusions}

Reports of two deaths from cell lodgement in the oesophagus have introduced a bias into the published reports on button cell ingestions, most cases of which can be managed conservatively and uneventfully. This bias, created by the reporting of a few highly atypical cases, combined with a presumption of alarming morbidity and mortality, has at times generated an overzealous approach. Endos- copy or surgery carry the risks of general anaesthesia and are only clearly indicated (1) if the cell is in the oesophagus, (2) if the cell remains fixed to the stomach or gut mucosa for a prolonged period, or (3) if there are signs of peritonitis. Where an undischarged mercury cell falls apart in the stomach there may be a very small hazard of mercury toxicity, and the management of such cases needs to be discussed on an individual basis with a poisons centre.

There is scope for prevention. The packaging of new cells could be made more secure, and labelling could draw attention to the need to keep cells away from children. Manufacturers could make the cell compartment of electrical devices less accessible to children and possibly make the casing of future cells less likely to corrode or fall apart.

\section{References}

1 Benson CD. Lloyd JR. Foreign bodies in the gastrointestinal tract. In: Ravitch MM. Welch KJ. Benson CD. Aberdeen E, Randolph JG, eds. Pediatric surgery. Vol 2. 3rd ed. Chicago: Year Book Medical Publishers, 1979:897-902.

2 Litovitz TL. Battery ingestions: product accessibility and clinical course. Pediatrics 1985;75:469-76.

3 Litovitz TL. Button battery ingestions. JAMA 1983:249: 2495-50)

+ Litovitz TL. Butterficld AB. Holloway RR. Marion LI. Button battery ingestion: assessment of therapeutic modalitics and battery discharge state. J Pediatr 1984:105:868-73.

Blatnik DS. Toohill RJ. Lehman RH. Fatal complications from an alkaline battery foreign body in the esophagus. Ann Otol Rhinol Laryngol 1977:86:611-5.

" Shabino CL. Feinberg AN. Esophageal perforation secondary to alkaline battery ingestion. JACEP 1979:8:361)-2.

7 Votteler TP, Nash JC, Rutledge JC. The hazard of ingested alkaline disk batteries in children. JAMA 1983;249:25(1)-6.

${ }^{\times}$Maves MD, Carithers JS, Birck HG. Esophageal burns secondary to disc battery ingestion. Ann Otol Rhinol Laryngol 1984:93:364-9.

"Langkau JF, Noesges RA. Esophageal burns from battery ingestion. Am J Einerg Med 1985:3:265.

1" Yamashita M. Naito H. Saito S. et al. Chemical burn duc to lowvoltage direct current-button type battery. Igaku Ayumi 1983:126:957-9.

$11 \mathrm{Jaffe}$ RB. Corncli HM. Fluoroscopic removal of ingested alkaline batteries. Radiology 1984:150:585-6.

12 Ito Y. Ihara N, Sohma S. Magnetic removal of alkaline batteries from the stomach. J Pediatr Surg 1985:20:250-1.

1.3 Mant TGK. Lewis JL. Mattoo TK, et al. Mercury poisoning following disc battery removal (in press).

${ }^{4}$ Barros D'Sa EA. Barros D'Sa AAB. Mercury battery ingestion Br Med J 1979:i:1218.

15 Barber TE, Menke RD. The relationship of ingested iron to the absorption of mercuric oxide. Am J Emerg Med 1984:2:5(1)-3.

16 Kulig K. Rumack CM. Duffy JP. Disk battery ingestion. Elevated urine mercury levels and enema removal of battery fragments. JAMA 1983:249:25(1)2-4.

17 Willis GA. Ho WC. Perforation of Meckel's diverticulum by an alkaline hearing aid battery. Can Med Assoc J 1982;126:497-8.

T J DAvid ANd A P Ferguson Booth Hall Children's Hospital, Manchester M9 $2 A A$, England 